\title{
Structure and function of zooplankton-associated bacterial communities in a temperate estuary change more with time than with zooplankton species
}

\author{
Samantha L. Bickel ${ }^{1, *}$, Kam W. Tang ${ }^{1}$, Hans-Peter Grossart ${ }^{2,3}$ \\ ${ }^{1}$ Virginia Institute of Marine Science, College of William and Mary, PO Box 1346, Gloucester Point, Virginia 23062, USA \\ ${ }^{2}$ Department of Limnology of Stratified Lakes, Leibniz Institute of Freshwater Ecology and Inland Fisheries, Alte Fischerhütte 2, \\ OT Neuglobsow, 16775 Stechlin, Germany \\ ${ }^{3}$ Institute for Biochemistry and Biology, Potsdam University, Maulbeerallee 2, 14469 Potsdam, Germany
}

\begin{abstract}
Zooplankton support distinct bacterial communities in high concentrations relative to the surrounding water, but little is known about how the compositions and functionalities of these bacterial communities change through time in relation to environmental conditions. We conducted a year-long field study of bacterial communities associated with common zooplankton groups as well as free-living bacterial communities in the York River, a tributary of Chesapeake Bay. Bacterial community genetic fingerprints and their carbon substrate usage were examined by denaturing gradient gel electrophoresis (DGGE) of amplified 16S rDNA and by Biolog EcoPlates, respectively. Zooplankton-associated communities were genetically distinct from free-living bacterial communities but utilized a similar array of carbon substrates. On average, bacteria associated with different zooplankton groups were genetically more similar to each other within each month $65.4 \%$ similarity) than to bacterial communities of the same zooplankton group from different months (28 to $30 \%$ similarity), which suggests the importance of ambient environmental conditions in shaping resident zooplankton-associated bacterial communities. Monthly changes in carbon substrate utilization were less variable for zooplankton-associated bacteria than for free-living bacteria, suggesting that the zooplankton microhabitat is more stable than the surrounding water and supports specific bacterial groups in the otherwise unfavorable conditions in the water column.
\end{abstract}

KEY WORDS: Zooplankton - Bacterial communities - Carbon substrates - Biolog EcoPlates · York River

\section{INTRODUCTION}

Zooplankton represent dynamic microhabitats for bacteria within aquatic systems, often supporting bacterial concentrations ranging from $10^{7}$ to $10^{11}$ cells $\mathrm{ml}^{-1}$ body volume which match or even exceed those in the surrounding water (Tang et al. 2010). Live zooplankton continually deliver organic matter into their guts through feeding, and produce dissolved organic matter through sloppy feeding and excretions, all of which can supplement the growth of zooplanktonassociated bacteria (Carman 1994, Tang et al. 2001,
Tang 2005, Møller et al. 2007). Zooplankton-associated bacterial communities may be seeded via the attachment of free-living bacteria or ingestion of free-living and food-associated bacteria (Hansen \& Bech 1996), whereby the physical conditions created within the zooplankton microenvironment may select for a specific bacterial community, i.e. a specific subset of the free-living and food-associated bacterial communities (Tang et al. 2010). While similar bacterial groups may be found on zooplankton and in the water column (Møller et al. 2007), the zooplanktonassociated bacterial community, as a whole, can be 
quite dissimilar from the free-living one (Grossart et al. 2009). Prior studies have focused primarily on bacteria associated with bulk zooplankton (Heidelberg et al. 2002, Parveen et al. 2011) or a single zooplankton species (Møller et al. 2007, Tang et al. 2009a, Freese \& Schink 2011, Homonnay et al. 2012). The few studies that have investigated co-occurring zooplankton found each zooplankton group supporting a different bacterial community (Niswati et al. 2005, Grossart et al. 2009, Brandt et al. 2010). Nevertheless, little is known about how bacterial community compositions (BCCs) of zooplankton co-occurring in the same habitat compare to each other and to free-living bacterial communities, or how their compositions change through time.

A number of studies have investigated temporal variability of free-living or total BCCs and the factors driving these changes. A recent review and metaanalysis showed that freshwater bacterial communities were highly correlated with $\mathrm{pH}$ and the ratio of dissolved organic carbon (DOC) to total phosphorus (Newton et al. 2011). Temporal patterns of estuarine and riverine free-living $\mathrm{BCC}$ have been related to temperature and chl a concentration (Kan et al. 2006) and river discharge (Crump \& Hobbie 2005). In their long-term study in lakes, Rösel et al. (2012) found consistent differences among re-occurring patterns of free-living and particle-associated bacteria. In particular, particle-associated bacteria were much more variable over time and their community composition was often directly related to phytoplankton and zooplankton dynamics. Moreover, Fuhrman et al. (2006) concluded that the distribution and abundance of specific microbial groups in a marine system can be predicted from environmental conditions such as temperature, oxygen, salinity, virus abundance and dissolved nitrate. Given that environmental parameters strongly influence the free-living bacterial community structure and that there is a constant exchange between zooplankton-associated and freeliving bacteria (Møller et al. 2007, Grossart et al. 2009, 2010), zooplankton-associated bacterial communities may be directly or indirectly shaped by environmental conditions as well and consequently exhibit seasonal changes.

In addition to environmental conditions, each zooplankton group may shape its own BCC due to differences in their lifestyle. For example, copepods and cladocerans collected from the same lake at the same time exhibited very different bacterial communities (Grossart et al. 2009). When the same cladocerans were transplanted into a different lake, they retained $>83 \%$ of their $\mathrm{BCC}$, indicating a rather stable bacter- ial assemblage regardless of the environment. In contrast, the copepod-associated bacteria were greatly influenced by the surrounding environment (Grossart et al. 2009). There are likely complex interactions between the environment and zooplankton themselves which may help to select for specific bacterial communities.

Generally, zooplankton-associated bacteria have higher production rates than their free-living counterparts (Carman 1994, Møller et al. 2007), but the underlying mechanisms such as carbon substrate utilization supporting this elevated production are largely unknown. Biolog EcoPlates ${ }^{\mathrm{TM}}$ offer an efficient method for assessing the ability of a mixed microbial assemblage to utilize 31 common carbon substrates. EcoPlates have been used to delineate carbon substrates utilized by free-living estuarine bacteria and bacteria associated with organic aggregates which function as microbial hotspots in aquatic systems and support bacteria that are more metabolically active and diverse than their free-living counterparts (Tang et al. 2006, Tang \& Grossart 2007, Lyons et al. 2010, Lyons \& Dobbs 2012).

The goal of this study was to assess the community compositions and functionalities of bacterial communities associated with multiple zooplankton groups and the free-living bacterial community over time within a temperate estuary. We hypothesized that each zooplankton group would support a genetically and functionally distinct bacterial community. Additionally, we sought to determine whether and which environmental conditions influence zooplanktonassociated bacterial community composition and functionality, causing seasonal changes. To address these goals, we conducted a year-long field study in the York River, a tributary of Chesapeake Bay on the east coast of the United States. The genetic and functional components of bacteria associated with the dominant meroplanktonic and holoplanktonic zooplankton groups were assessed each month, compared to the free-living bacteria, and related to environmental conditions.

\section{MATERIALS AND METHODS}

\section{Sample collection}

Zooplankton were collected on a monthly basis from May 2010 to April 2011 at a fixed station in the York River, Virginia ( $37^{\circ} 14^{\prime} 50.36^{\prime \prime}$ N, $76^{\circ} 29^{\prime} 58.03^{\prime \prime} \mathrm{W}$ ), with a $0.5 \mathrm{~m}$ mouth diameter, $200 \mu \mathrm{m}$ mesh net. All samples were collected at high or near high tide dur- 
ing daylight hours, and transported immediately back to the laboratory. In the lab, each sample was split into 4 equal fractions. Each fraction was gently concentrated onto a $200 \mu \mathrm{m}$ mesh sieve and transferred to sterile filtered Instant Ocean ${ }^{\circledR}$ artificial seawater (ASW), where the zooplankton were allowed to clear their guts overnight to eliminate food-associated bacteria. After gut clearance, sub-samples were used to assess (1) zooplankton-associated bacterial genetic fingerprint via denaturing gradient gel electrophoresis (DGGE) of 16S rDNA amplified using eubacterial primers, (2) zooplankton-associated bacterial functionality via carbon substrate usage measured by Biolog EcoPlates, and (3) zooplankton community composition. The fourth subsample was used for additional zooplankton-associated bacterial measurements and will be reported elsewhere.

The sub-sample for zooplankton community composition was filtered onto a $200 \mu \mathrm{m}$ nitex mesh dish and frozen at $-40^{\circ} \mathrm{C}$ until analysis. Zooplankton were identified to the lowest practical taxon. Relative percentages of each zooplankton group within the sampled community were calculated for each month.

Water samples were collected at the same time as the zooplankton; water temperature, salinity, chl $a$, ammonium, phosphate, and abundance and community composition of free-living bacteria were determined. Chl a was extracted from the filters with $90 \%$ acetone and measured fluorometrically. Ammonium concentrations were measured in duplicate on a Shimadzu UV-1601 spectrophotometer following the phenol hypochlorite method (detection limit $0.05 \mu \mathrm{mol} \mathrm{N}{ }^{-1}$; Koroleff 1983). Phosphate concentrations were run in duplicate on a Lachat QuikChem 8500 autoanalyzer (detection limit $0.05 \mathrm{\mu mol} \mathrm{l}^{-1}$; Parsons et al. 1984). Free-living bacterial abundance was counted in triplicate by DAPI direct counts (Porter \& Feig 1980). To assess the genetic composition of freeliving bacteria, approximately $60 \mathrm{ml}$ of $5 \mu \mathrm{m}$ prefiltered York River water was filtered on to a $0.2 \mu \mathrm{m}$ pore size polycarbonate membrane filter and stored at $-40^{\circ} \mathrm{C}$ until analysis.

\section{DNA extraction and DGGE}

After gut clearance, zooplankton were gently concentrated onto a sterile $200 \mu \mathrm{m}$ mesh sieve and rinsed 3 times with sterile filtered ASW to remove any freeliving or loosely attached bacteria. Zooplankton were back-rinsed into a sterile Petri dish and narcotized with sodium bicarbonate. Preliminary experiments indicated that narcotization with sodium bicarbonate did not influence the abundance of zooplanktonassociated bacteria. Two or 3 replicates of 5 to 10 individuals of the same zooplankton species were transferred to a sterile microcentrifuge tube, preserved in $95 \%$ molecular biology grade ethanol and stored at $-40^{\circ} \mathrm{C}$ until analysis. Consistent DGGE banding patterns have been attained previously regardless of the number of individuals used for analysis (Brandt et al. 2010). Zooplankton samples were centrifuged for $2 \mathrm{~min}$ at room temperature at $17000 \times g$ to pellet out the zooplankton and any bacteria that may have detached from the zooplankter during the preservation process. Excess ethanol was pipetted off after centrifugation and discarded. Zooplankton-associated and free-living bacterial DNA was extracted using the phenol-chloroform-isoamylalcohol method with smoldered zirconia beads (Zhou et al. 1996). Extracted DNA was checked for quality and quantity on a UV/ VIS Spectrophotometer (NanoPhotometer ${ }^{\mathrm{TM}}$ Implen). PCR amplified for DGGE using eubacterial primers 341f-gc with a 5' GC clamp (5' CGC CCG CCG CGC CCC GCG CCC GTC CCG CCG CCC CCG CCC GCC TAC GGG AGG CAG CAG 3') and 907r (5' CCG TCA ATT CMT TTG AGT TT 3') (Muyzer \& Ramsing 1995). Each $50 \mu \mathrm{l}$ PCR reaction contained

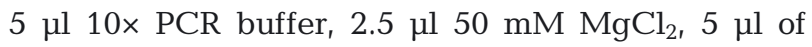
$2.5 \mathrm{mM}$ dNTP, $10 \mathrm{pmol}$ of each primer, $0.5 \mu \mathrm{lBA}$, $0.5 \mu \mathrm{l}$ red-Taq DNA polymerase (Bioline), 2 to $3 \mu \mathrm{l}$ of template DNA (approximately 20 ng DNA template) and was brought to volume with PCR water. The PCR cycling program was as follows: initial denaturation for $3 \mathrm{~min}$ at $95^{\circ} \mathrm{C}$ followed by 35 cycles of 1 min denaturation at $95^{\circ} \mathrm{C}, 1 \mathrm{~min}$ annealing at $54^{\circ} \mathrm{C}, 2$ min extension at $72^{\circ} \mathrm{C}$ with a final extension at $72^{\circ} \mathrm{C}$ for $10 \mathrm{~min}$.

DGGE was performed according to Tang et al. (2009b). An average of $540 \mathrm{ng}$ PCR product was loaded into each well of a $7 \%$ acrylamide gel with 40 to $70 \%$ denaturing gradients (formamide and urea). Gels were run at $100 \mathrm{~V}$ for $18 \mathrm{~h}$ then stained with $1 \mathrm{X}$ SYBR-gold for $30 \mathrm{~min}$, destained with Milli-Q water and imaged on a UV light table. Due to limited space on each DGGE gel, only 1 replicate of each sample was run on the analyzed gels. Preliminary analyses indicated a high degree of similarity among replicate samples (average of $90.5 \%$ similarity), with the exception of samples from June.

\section{Carbon substrate utilization}

For samples collected from August 2010 to April 2011, Biolog EcoPlates were used to assess each bacterial community's ability to utilize a variety of car- 
bon substrates. EcoPlates contain triplicate wells of 31 carbon substrates, and control wells with no substrate addition to account for any carbon substrates added with the inocula. Each well also contains minimal growth media and the redox dye, tetrazolium violet, which changes from colorless to purple in the presence of electron transfer, indicating bacterial usage of the respective substrate (Bochner 1989). Carbon sources can be grouped into the larger biochemical categories of polymers, carbohydrates, carboxylic acids, amino acids, amines and phenolic compounds (see Table 3 below; Choi \& Dobbs 1999).

After they cleared their guts, zooplankton were concentrated onto a sterile sieve, rinsed and backrinsed into a sterile Petri dish as described previously but without narcotization. Twenty-five to 35 individuals of each of the most abundant zooplankton groups were picked and transferred to sterile $15 \mathrm{ml}$ centrifuge tubes with $5 \mathrm{ml}$ of sterile filtered, autoclaved York River water. Preliminary experiments indicated the number of individuals used did not impact substrate usage patterns (S. Bickel, unpubl. data). To assess the free-living bacterial community, $5 \mathrm{ml}$ of $5 \mu \mathrm{m}$ filtered York River water was added to a sterile $15 \mathrm{ml}$ centrifuge tube. Each sample was sonicated for $40 \mathrm{~s}$ on ice with an ultrasonic homogenizer at $4 \mathrm{~W}$ output power to break apart zooplankton bodies and dislodge any attached bacteria (modified from Tang 2005). Microscopic inspection verified that sonication effectively dislodged bacteria from the zooplankton tissue. Samples were brought to $15 \mathrm{ml}$ final volume with sterile filtered, autoclaved York River water and centrifuged for $10 \mathrm{~min}$ at $102 \times g$ to precipitate any zooplankton debris. The supernatant was gently pipetted into a sterile loading chamber and $150 \mu \mathrm{l}$ of supernatant was added to each well of the EcoPlate. Free-living bacterial samples were processed in the same manner as zooplankton samples. Optical density (OD) ( $\lambda=590 \mathrm{~nm}$ ) of each well was measured immediately with a BioTek EXL800 plate reader and again after a 7 - $\mathrm{d}$ incubation at $19^{\circ} \mathrm{C}$ in the dark. Final OD measurements of each well were adjusted by subtracting initial OD for each well and the average absorbance of the control was subtracted from the average absorbance of each substrate. Individual substrate usage was expressed as the average substrate color development (ASCD). The ASCD was calculated by dividing the OD of the substrate by the sum of ODs from all substrates and averaging the triplicate values for each substrate. ASCD was then expressed as a percent. This accounts for differences in inoculum densities, the triplicate measurements of each substrate on the Ecoplate, and any color devel- opment in control wells (Montserrat Sala et al. 2006). A substrate was considered used if it contributed to at least $2 \%$ of the total absorbance of all substrates (Montserrat Sala et al. 2006, Lyons \& Dobbs 2012). The total number of substrates utilized by the microbial community was used as a measure of functional potential of the heterotrophic community (Zak et al. 1994). Each individual zooplankter supported approximately $10^{5}$ bacteria (see 'Results') which led to an initial inoculum density of $10^{5}$ cells $\mathrm{ml}^{-1}$ for zooplankton-associated bacteria. Likewise, free-living bacteria inoculum densities were $10^{5} \mathrm{ml}^{-1}$. While this is at the very low end of recommended inoculum densities (Konopka et al. 1998), Christian \& Lind (2006) demonstrated that inoculum density had no impact on average well color development after $72 \mathrm{~h}$ of incubation.

\section{Statistical analyses}

Cluster analysis of DGGE banding patterns was performed with GELCOMPAR II, v.3.5 (Applied Maths) using the unweighted pair group method with arithmetic averages. Cluster analysis of carbon substrate utilization patterns was performed in PRIMER6 (PRIMER-E), also using the unweighted pair group method with arithmetic mean (UPGMA). Pairwise similarity matrices were calculated for presence/absence of both DGGE banding patterns and carbon substrate utilization patterns using the Dice similarity index (Dice 1945). Multidimensional scaling (MDS) was performed in PRIMER6 using the Dice similarity matrices to determine the genetic and functional similarities of the different bacterial communities based on their distances from each other on a 2-dimensional plot. Significance of the observed similarities and differences was assessed with analysis of similarity (ANOSIM) in PRIMER6. Water quality parameters were analyzed with the multivariate statistical method of canonical correspondence analysis (CCA) to determine which environmental parameters contributed to the presence or absence of specific DGGE bands, or use of particular substrates among zooplankton-associated and free-living bacterial communities. The environmental parameters included temperature, salinity, chl $a$, ammonium, phosphate, free-living bacterial abundance and zooplankton-associated bacterial abundance. All CCA analyses were performed with the vegan package (Oksanen et al. 2012) in R statistical software (version 2.15.2, R Core Team 2012). All explanatory variables were initially included in CCA analyses and then tested for collinearity by examining variance infla- 
tion factors (VIF) in R. If VIFs were greater than 10, the variable with the highest VIF was removed from the model until all VIFs were less than 10 (Borcard et al. 2011).

\section{RESULTS}

\section{Environmental parameters}

Water temperatures were lowest in winter $\left(3.5^{\circ} \mathrm{C}\right.$ in January), increased through spring and early summer to a peak of $30.5^{\circ} \mathrm{C}$ in July, and then decreased again in fall (Table 1). Salinity was typically between 20 and 24.5, with the exception of May 2010, when it was only 17.5 (Table 1). Ammonium reached its highest concentration in late summer $\left(6.92 \mu \mathrm{mol} \mathrm{l}^{-1}\right.$ in August). In contrast, phosphate was lowest in late spring and peaked in December $\left(0.56 \mu \mathrm{mol}{ }^{-1}\right)$. Chl a concentration was lowest in December, increased

Table 1. Monthly water quality measurements and free-living bacterial abundances for the York River, Virginia, USA, during the field study. BLD: below level of detection

\begin{tabular}{|lcccccc|}
\hline Date & $\begin{array}{c}\text { Water } \\
\text { temperature } \\
\left({ }^{\circ} \mathrm{C}\right)\end{array}$ & Salinity & $\begin{array}{c}\text { Ammonium } \\
\left(\mu \mathrm{mol} \mathrm{l}^{-1}\right)\end{array}$ & $\begin{array}{c}\text { Phosphate } \\
\left(\mu \mathrm{mol} \mathrm{l}^{-1}\right)\end{array}$ & $\begin{array}{c}\text { Chl a } \\
\left(\mu \mathrm{l}^{-1}\right)\end{array}$ & $\begin{array}{c}\text { Free-living bacte- } \\
\text { rial abundance } \\
\left(10^{6}{\left.\text { cells } l^{-1}\right)}^{-1}\right.\end{array}$ \\
\hline May 2010 & 22.5 & 17.5 & 0.56 & BLD & 2.69 & 3.65 \\
Jun 2010 & 28.0 & 22.0 & 3.87 & BLD & 3.52 & 3.27 \\
Jul 2010 & 30.5 & 22.0 & 1.11 & 0.21 & 2.48 & 1.42 \\
Aug 2010 & 28.5 & 23.5 & 6.92 & 0.36 & 2.71 & 3.90 \\
Sep 2010 & 26.0 & 24.0 & 3.76 & 0.22 & 0.71 & 3.76 \\
Oct 2010 & 16.0 & 23.0 & 3.08 & 0.31 & 0.18 & 2.31 \\
Nov 2010 & 13.0 & 22.0 & 1.62 & 0.49 & 4.15 & 1.71 \\
Dec 2010 & 4.0 & 24.5 & 1.64 & 0.56 & 0.03 & 1.20 \\
Jan 2011 & 3.5 & 24.0 & 0.39 & 0.45 & 0.38 & 0.94 \\
Feb 2011 & 9.0 & 23.0 & 0.45 & 0.03 & 3.69 & 1.04 \\
Mar 2011 & 11.0 & 21.0 & 1.03 & 0.08 & 3.22 & 1.05 \\
Apr 2011 & 16.0 & 20.0 & 0.54 & 0.03 & 6.34 & 0.91 \\
\hline
\end{tabular}

during late winter and peaked in early spring. Freeliving bacterial abundance followed a trend similar to temperature, with highest abundances in summer, decreasing through fall to lowest values in winter (Table 1).

\section{Zooplankton community composition and associated bacterial abundances}

The calanoid copepod Acartia sp. was present yearround and comprised 23 to $99 \%$ of the zooplankton community (Table 2). The barnacle nauplius Balanus sp. was the second most common zooplankter, present in 10 of 12 mo and comprising 5 to $55 \%$ of the zooplankton community. Other common zooplankton included polychaete larvae, harpacticoid copepods, the cladoceran Podon sp., and the calanoid copepods Parvocalanus sp., Pseudodiaptomus sp. and Centropages sp. (Table 2). The average number of bacteria per individual zooplankter was on the order of $10^{5}$ with peaks in abundances observed in August and December/January. The highest average abundance per individual was $8.25 \times 10^{5}$ on harpacticoid copepods in August and the lowest was $0.15 \times 10^{5}$ on the calanoid copepod Pseudodiaptomus sp. in January. The average number of bacteria per Acartia ranged from $0.67 \times 10^{5}$ in January to $5.71 \times 10^{5}$ in August. The average number of bacteria per individual Balanus ranged from $0.25 \times 10^{5}$ in May to $7.41 \times 10^{5}$ in January.

Table 2. Zooplankton community composition in the York River, Virginia, USA, in monthly samples taken between May 2010 and April 2011

\begin{tabular}{|c|c|c|c|c|c|c|c|c|c|c|c|c|}
\hline \multirow{2}{*}{ Taxon/group } & \multicolumn{12}{|c|}{ - \% total zooplankton } \\
\hline & May & Jun & Jul & Aug & Sep & Oct & Nov & Dec & Jan & Feb & Mar & Apr \\
\hline Acartia & 27.12 & 87.71 & 99.08 & 75.18 & 50.68 & 30.34 & 94.34 & 91.74 & 67.47 & 48.23 & 23.09 & 38.26 \\
\hline Balanus & 55.02 & 5.53 & 0.00 & 16.31 & 23.24 & 8.72 & 0.00 & 4.96 & 24.15 & 15.71 & 52.79 & 53.62 \\
\hline Polychaete larvae & 5.50 & 0.00 & 0.00 & 0.00 & 0.25 & 1.25 & 0.21 & 0.41 & 1.45 & 8.65 & 0.29 & 0.50 \\
\hline Podon & 9.27 & 0.00 & 0.00 & 0.00 & 5.19 & 0.09 & 0.00 & 0.21 & 0.16 & 0.24 & 0.00 & 1.19 \\
\hline Harpacticoids & 0.58 & 0.00 & 0.00 & 0.71 & 0.00 & 7.38 & 0.00 & 0.41 & 0.64 & 0.12 & 0.00 & 0.40 \\
\hline Parvocalanus & 0.48 & 0.00 & 0.23 & 1.42 & 12.61 & 13.79 & 0.00 & 0.41 & 1.45 & 5.36 & 3.82 & 0.50 \\
\hline Pseudodiaptomus & 0.39 & 0.00 & 0.69 & 2.84 & 4.45 & 35.77 & 4.19 & 1.65 & 0.48 & 1.83 & 7.79 & 4.46 \\
\hline Centropages & 0.00 & 0.00 & 0.00 & 0.00 & 0.00 & 0.00 & 0.00 & 0.00 & 3.38 & 19.00 & 8.68 & 0.50 \\
\hline Other & 1.64 & 6.76 & 0.00 & 3.55 & 3.58 & 2.67 & 1.26 & 0.21 & 0.81 & 0.85 & 3.53 & 0.59 \\
\hline
\end{tabular}




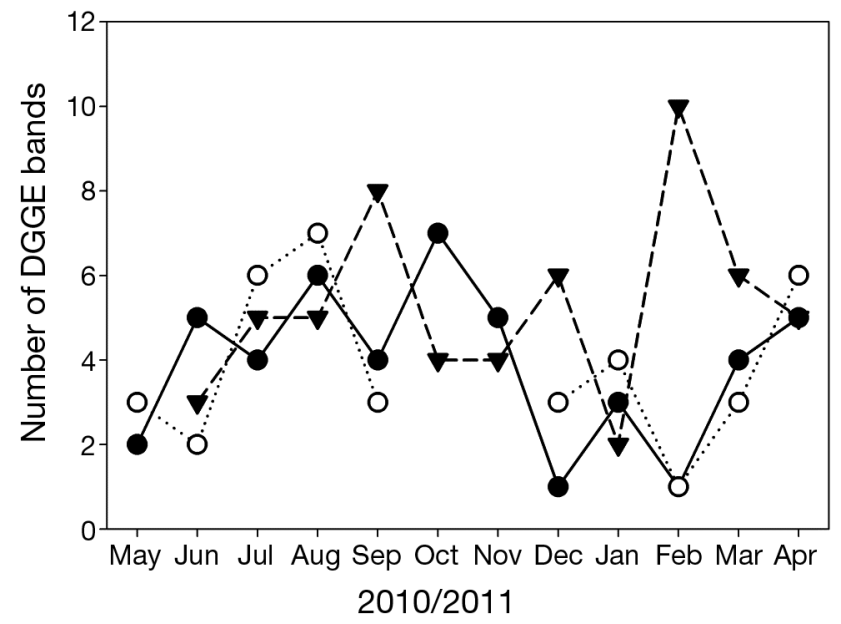

Fig. 1. Total number of denaturing gradient gel electrophoresis (DGGE) bands present in monthly samples of zooplankton-associated and free-living bacterial communities in the York River, Virginia, USA: (@) Acartia; (O) Balanus;

$(\boldsymbol{\nabla})$ free-living bacteria

\section{Bacterial community composition}

There was a large month to month variation in the number of DGGE bands in each of the zooplanktonassociated bacterial communities. The Acartia-associated bacterial community ranged from only 1 band in December and February to 7 bands in October. Similarly, Balanus-associated bacteria ranged from 1 band in February to 7 bands in August. Freeliving bacteria ranged from 2 bands in January to 10 bands in February (Fig. 1). The patterns of DGGE band abundance were similar for Acartia and Balanus, with the highest number of DGGE bands observed in the late summer and fall and the lowest numbers observed in winter, with the exception of June Balanus (Fig. 1). During some months, different zooplankton groups supported a similar number of DGGE bands (e.g. mysid, crab zoea and Acartia each supported 4 DGGE bands in July; data not shown), while the number of bands per zooplankton group were drastically different in other months (e.g. Pseudodiaptomus contained 4 DGGE bands and Acartia supported 7 bands in October; data not shown). On an annual average, the free-living bacterial community contained more DGGE bands, with 5.27 bands per month, while Acartia- and Balanus-associated bacterial communities had 3.91 and 3.80 bands, respectively.

Although the zooplankton-associated and freeliving bacterial communities contained similar numbers of DGGE bands, the composition of the bacterial community (determined by the position of the
DGGE bands within the gel) was notably different. Cluster analysis (Fig. 2A) and MDS (Fig. 2B) indicated that free-living bacterial communities were dissimilar $(<10 \%$ similar $)$ from all zooplanktonassociated bacterial communities. ANOSIM confirmed the dissimilarity between zooplankton-associated bacteria and free-living bacteria $(\mathrm{R}=0.372, \mathrm{p}<$ 0.001). Within the free-living bacteria there were 2 main groups: a winter/spring group (December through April) and a summer/fall group (May through November). Within each month, similarities among bacterial communities associated with different zooplankton groups ranged from $22 \%$ in June to $100 \%$ in February (Fig. 2A, average 65.4\%), and
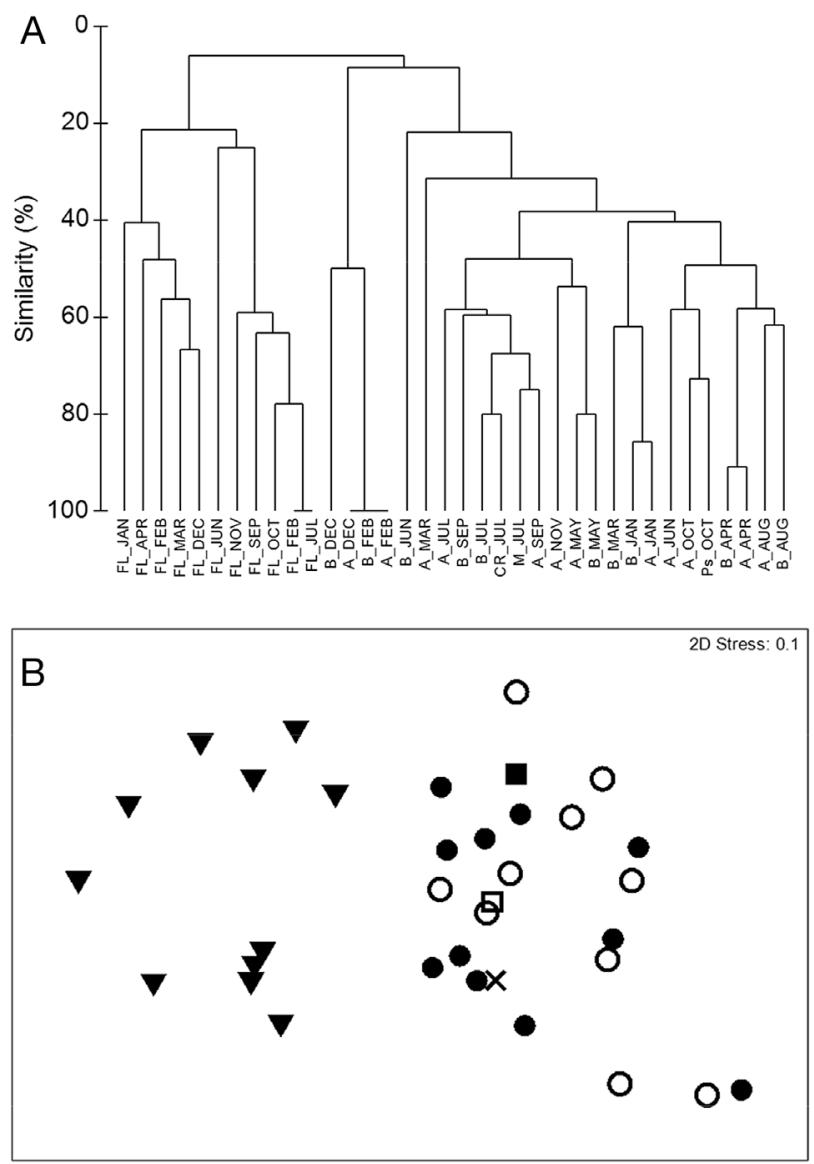

Fig. 2. (A) UPGMA dendrogram of similarities among DGGE banding patterns for monthly samples of zooplanktonassociated and free-living bacterial communities collected from the York River, Virginia, USA, from May 2010 to April 2011. Dendrogram abbreviations show taxon/group and month of sampling. $\mathrm{CR}=$ crab zoea; all other abbreviations are the same as those used in Table 3. (B) MDS plot for DGGE banding patterns of zooplankton-associated and free-living bacteria. $\bullet$ : Acartia $(\mathrm{n}=12)$; O: Balanus $(\mathrm{n}=10)$; $\boldsymbol{\nabla}$ : free-living bacteria $(\mathrm{n}=11) ; \square$ : crab zoea $(\mathrm{n}=1)$; Pseudodiaptomus $(\mathrm{n}=1) ; \times$ : mysid $(\mathrm{n}=1)$ 
the differences in bacterial communities of different zooplankton were not significant (ANOSIM, global $\mathrm{R}=-0.116, \mathrm{p}=0.939$ ). Although there were no distinct seasonal groupings among the zooplanktonassociated bacteria, there were significant difference in zooplankton-associated bacterial communities among months (ANOSIM, global $\mathrm{R}=0.835, \mathrm{p}=$ $0.001)$.

\section{Bacterial substrate usage}

Substrate usage was highest in October for Acartia-associated, Balanus-associated and polychaete larvae-associated bacteria (28, 29 and 27 substrates, respectively; Fig. 3) and in November for freeliving bacteria (20 substrates; Fig. 3). Substrate usage was lowest in August for both Acartia-associated (14) and Balanus-associated bacteria (13); polychaete larvae-associated bacteria used 15 substrates in September. Free-living bacteria used 17 substrates in March and April (Fig. 3). Within each month, zooplankton-associated bacteria used a similar number of substrates as free-living bacteria (Fig. 3). On an annual average, Acartia-associated bacteria used 18.4 substrates, Balanus-associated bacteria 17.1 substrates, polychaete larvae-associated bacteria 18.6 substrates, and free-living bacteria 18.0 substrates. Free-living bacteria and Acartia-associated bacteria regularly utilized substrates from all of the tested biochemical categories. Balanus and polychaete-associated bacteria also regularly utilized all biochemical categories except phe-

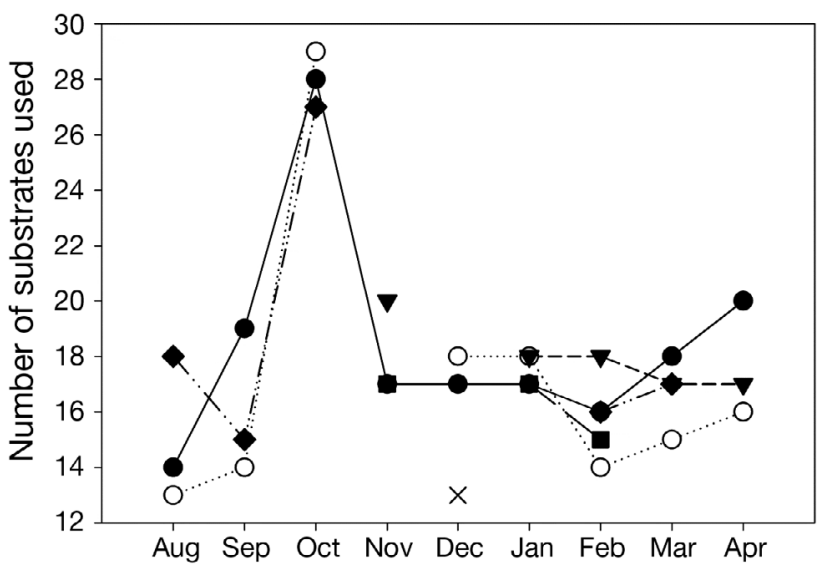

Fig. 3. Total number of carbon substrates utilized by zooplankton-associated and free-living bacteria communities collected between August 2010 and April 2011. @: Acartia; O: Balanus; $\mathbf{\nabla}$ : free-living bacteria; $\mathbf{\square}$ : calanoid copepods; ४ polychaete larvae; $X$ : mysid nolic compounds (Table 3). The most commonly used substrates among all samples were the carboxylic acid pyruvic acid methyl ester, the polymer Tween 40 and the carbohydrate N-acetyl-Dglucosamine (Table 3). There was some overlap of carbon substrate utilization patterns between freeliving bacteria and zooplankton-associated bacteria (Fig. 4B). Substrate utilization patterns of freeliving bacteria from February and November were 72 to $74 \%$ similar to substrate usage of all zooplankton collected in October (Fig. 4A). Substrate usages by free-living bacteria from January, March and April were approximately 59\% similar to those of Acartia-associated bacteria in April and November (Fig. 4A). Within a particular month, the average similarity of substrate usage between free-living bacteria and any zooplankton-associated bacteria was $57.7 \%$. ANOSIM indicated no significant difference in substrate usage profiles between freeliving and zooplankton-associated bacteria (global $\mathrm{R}=0.055, \mathrm{p}=0.242$ ). Within each month, substrate usage profiles for bacteria associated with different zooplankton groups were not significantly different (global $\mathrm{R}=-0.077, \mathrm{p}=0.804$ ), with 35.3 to $94.0 \%$ similarity (average 69.4\%; Fig. 4). However, substrate usage by zooplankton-associated bacterial communities was significantly different among months (global $\mathrm{R}=0.301, \mathrm{p}=0.002$ ). When both DGGE and substrate usage patterns were considered, both Acartia- and Balanus-associated bacteria had fewer DGGE bands but used a similar number of substrates as free-living bacteria.

\section{Relationship with environmental factors}

Measured environmental parameters accounted for $37.6 \%$ of genetic variability in all zooplanktonassociated bacteria (Fig. 5A). The first 2 canonical axes accounted for 10.8 and $9.7 \%$ of the variability, respectively. Three DGGE bands (18, 21 and 26) were related to high salinity, high phosphate and high zooplankton-associated bacterial abundance. Many of the bands were not related to measured environmental parameters. A higher proportion of the variation (65.8\%) among Acartia-associated bacteria (Fig. 5B) was explained by environmental conditions. Again, Bands 21 and 26 were linked to high salinity and high phosphate, and a number of bands were not explained by measured environmental variables. Free-living bacterial abundance was removed from CCA analyses of DGGE banding for free-living bacteria due to collinearity. Among the free-living 
Table 3. Monthly carbon substrate utilization by zooplankton-associated and free-living bacteria of the York River, Virginia, USA, sampled between August 2010 and April 2011. Black squares indicate the substrate was used. Carbon substrates are grouped according to their biochemical category ('P.C.' indicates phenolic compounds). Substrate numbers correspond to numbers used in canonical correspondence analysis (CCA) of the EcoPlate data (see Fig. 6). Samples are coded by taxon/ group and month of sampling; not all zooplankton groups were present in all months. A: Acartia; B: Balanus; Po: polychaete larvae; Ps: Pseudodiaptomus; C: Centropages; M: mysid; FL: free-living

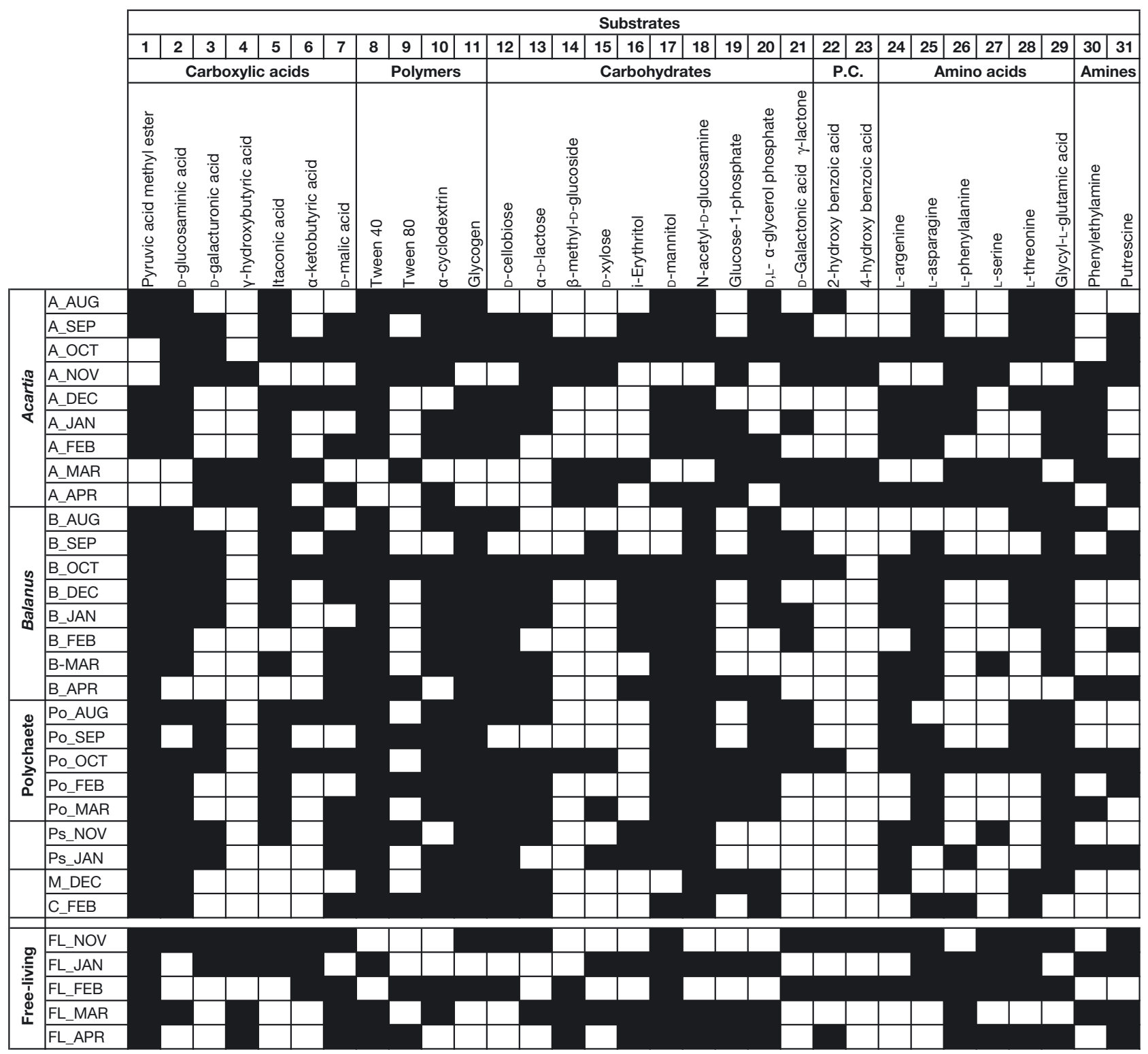

bacteria (Fig. 5C), environmental parameters accounted for $52.2 \%$ of the variability in the bacterial community composition, with the first and second axes contributing $24.7 \%$ and $11.6 \%$, respectively. Four DGGE bands (4, 5, 11 and 20) were linked to high chl a concentrations. Another group of bacteria (Bands 2, 17 and 35) was linked to high temperatures.

Due to high degrees of collinearity with measured environmental parameters, free-living bacterial abun- dance and zooplankton-associated bacterial abundance were removed from CCA analyses of carbon substrate usage. Measured environmental parameters explained only $25.2 \%$ of variability in substrate usage among all zooplankton-associated bacteria (Fig. 6A). The first 2 canonical axes accounted for $14.7 \%$ and $4.4 \%$, respectively. The use of 8 substrates (2 carbohydrates, 2 phenolic compounds, 2 amino acids, 1 carboxylic acid and 1 amine) was 

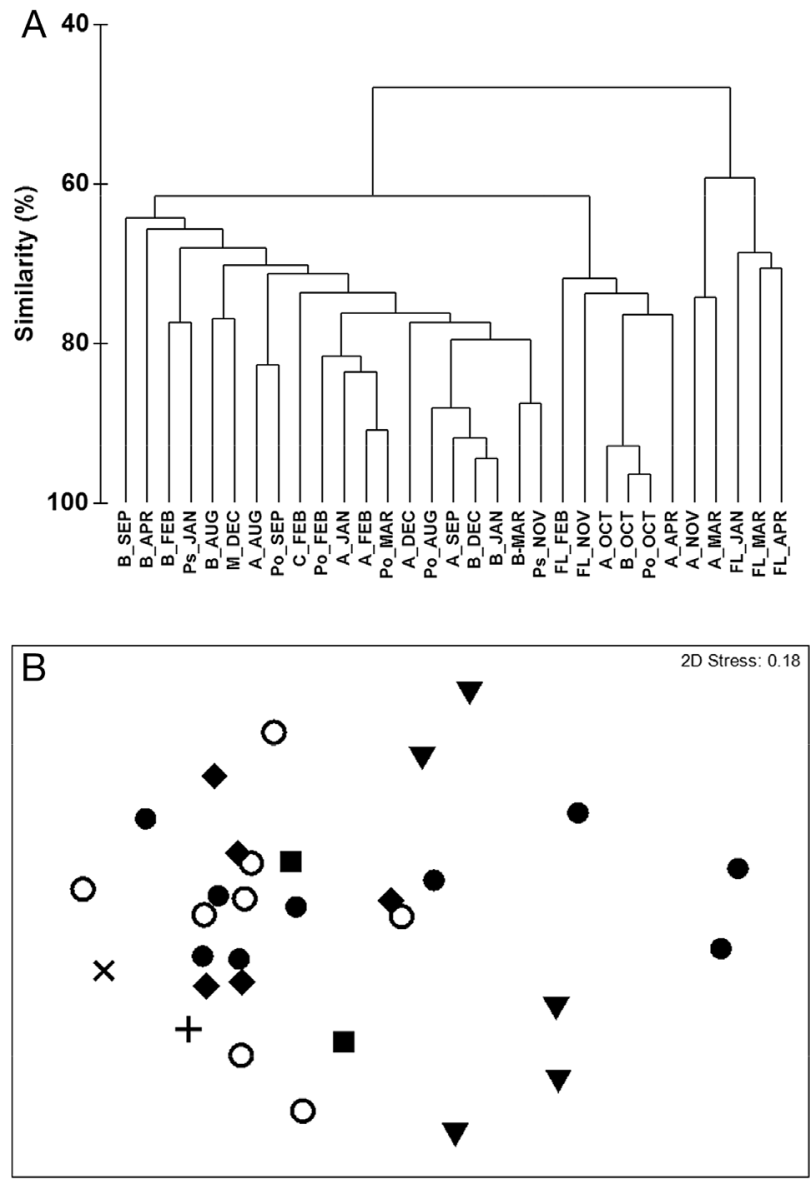

Fig. 4. (A) UPGMA dendrogram of carbon substrate usage profiles for zooplankton-associated and free-living bacterial communities collected from the York River, Virginia, USA, between August 2010 and April 2011. Dendrogram abbreviations show taxon/group and month and are the same as those used in Table 3. (B) MDS plot of carbon substrate usage profiles for zooplankton-associated and free-living bacteria: - Acartia $(\mathrm{n}=9)$; O: Balanus $(\mathrm{n}=8) ; \boldsymbol{\nabla}$ : free-living bacteria $(\mathrm{n}=5) ;+$ : Centropages $(\mathrm{n}=1) ; \mathbf{\square}$ : Pseudodiaptomus

$(\mathrm{n}=2) ; \mathrm{X}$ : mysid $(\mathrm{n}=1) ;$ : polychaete larvae $(\mathrm{n}=5)$

linked to high chl a concentrations, while the use of 4 substrates ( 2 carboxylic acids, 1 amino acid and 1 carbohydrate) was linked to high phosphate levels. When only Acartia-associated bacteria were examined (Fig. 6B), $78.5 \%$ of variation in substrate usage was explained by measured environmental conditions, with the first 2 axes accounting for $44.0 \%$ and

Fig. 5. CCA biplots illustrating the relationship between environmental variables and presence of DGGE bands from (A) all zooplankton-associated bacteria, (B) Acartia-associated bacteria and (C) free-living bacteria. DGGE bands present in the gel were arbitrarily numbered 1 through 36. Bact: freeliving bacterial abundance; Zoobact: zooplankton-associated bacterial abundance; Sal: salinity; Chl: chlorophyll a, PO4: phosphate; NH4: ammonium; Temp: temperature
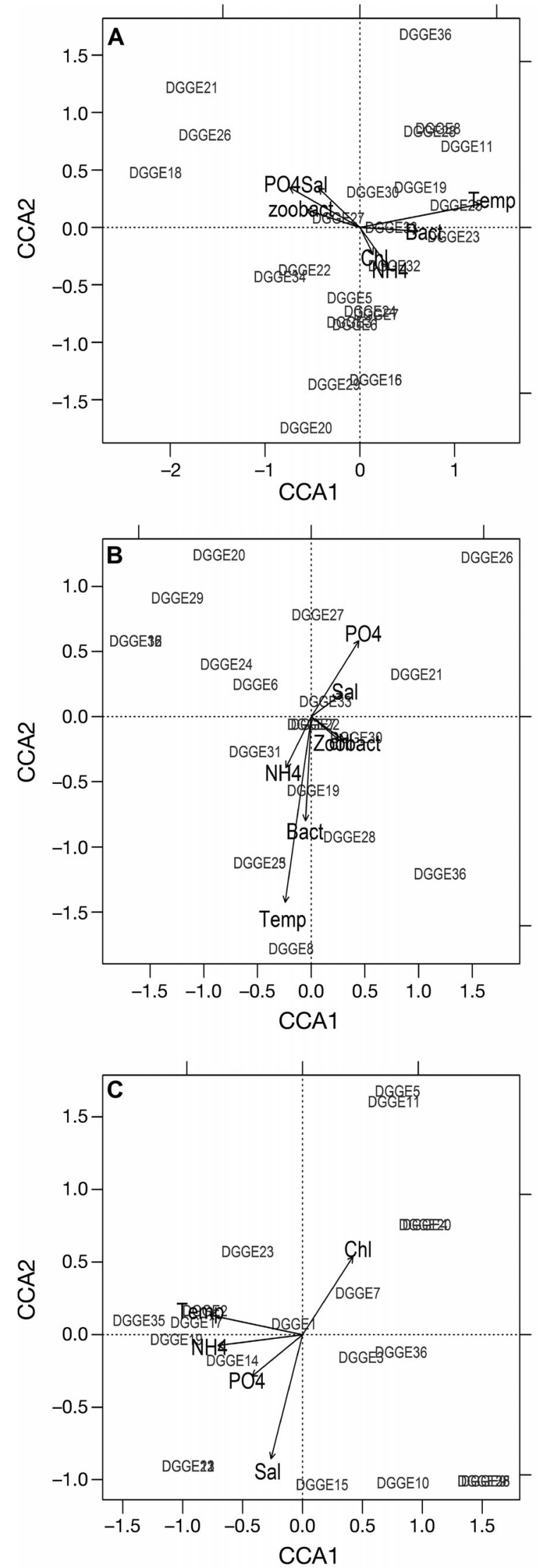

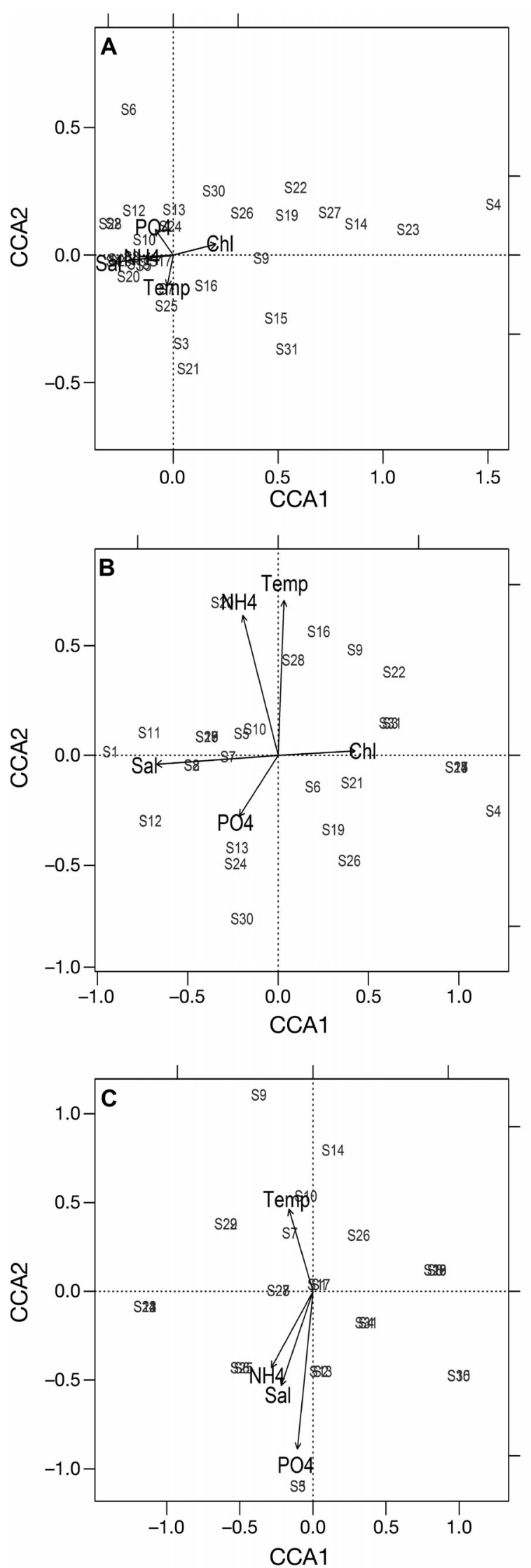

$13.2 \%$, respectively. Again, 8 substrates were linked to $\mathrm{chl}$ a concentration (2 carbohydrates, 2 phenolic compounds, 2 carboxylic acids 1 amino acid and 1 amine). Usage of L-argenine, $\alpha$-D- lactose and phenylethylamine was tied to high phosphate concentrations Use of D-L- $\alpha$ glycerol phosphate was linked to ammonium concentrations and higher temperatures. Measured environmental conditions explained all variations $(100 \%)$ among substrate usage by free-living bacteria (Fig. 6C). Usage of Tween 80 was linked to higher salinity, while the usage of D-glucosaminic acid and Itaconic acid was linked to phosphate. The most commonly used substrates among all sample types (pyruvic acid methyl ester, Tween 40 and $\mathrm{N}$-acetyl D-glucosamine) did not exhibit a strong association with any measured environmental conditions.

\section{DISCUSSION}

\section{Comparison of zooplankton-associated bacterial communities}

Previous DGGE analyses of zooplankton-associated bacteria showed distinctly different banding patterns among different zooplankton groups (Niswati et al. 2005, Grossart et al. 2009, Brandt et al. 2010); however, none of these studies quantified the level of similarity among the bacterial communities. The results of the current study are similar to those of Gerdts et al. (2013) who found no significant differences in the bacterial communities associated with 4 different calanoid copepods in the North Sea. The small differences in BCC of co-occurring zooplankton suggest that zooplankton-specific characteristics such as food preference or excretion rates may still influence the associated bacterial community composition. During the exchange between freeliving, food-associated, and zooplankton-associated communities (Harris 1993, Grossart et al. 2010, Grossart \& Tang 2010), the microenvironment created by each zooplankter may act as a selective filter, concentrating a specific, distinct bacterial community, which ultimately depends on the initial bacterial community to which the zooplankter was exposed.

Fig. 6. CCA biplots illustrating relationship between environmental conditions and the usage of specific carbon substrates by (A) all zooplankton-associated bacteria, (B) Acartia-associated bacteria and (C) free-living bacteria. The substrates were denoted as S1 through S31 as defined in Table 3. See

Fig. 5 legend for definitions of other abbreviations 


\section{Temporal changes in zooplankton-associated bacteria}

With one exception (Gerdts et al. 2013), previous studies provided a limited snapshot of zooplanktonassociated bacterial communities. Consequently, temporal changes and impacts of changing environmental conditions have not been fully explored. Bacterial communities associated with calanoid copepods in the North Sea showed no change across seasons (Gerdts et al. 2013); however, environmental conditions within the North Sea region (e.g. temperature and salinity; Reiss \& Kröncke 2005) may not fluctuate as widely as in the York River. The large monthly changes we observed in composition (Fig. 2) and functionality (Fig. 4) of bacteria associated with each zooplankton group suggest that the physical, chemical and biological conditions of the ambient environment are largely responsible for shaping the bacterial communities, which are then further refined by the zooplankton microenvironment.

The most commonly used substrates were responsible for the similarities in substrate usage through time and suggest that zooplankton-associated bacteria are able to utilize both ambient and zooplanktonderived substrates. Both pyruvic acid methyl ester and Tween 40 are used by bacteria isolated from coral (Ritchie \& Smith 1995) and marine aggregates (Lyons et al. 2010, Lyons \& Dobbs 2012), and by free-living bacteria in marine and estuarine systems (Montserrat Sala et al. 2005, 2006, Lyons \& Dobbs 2012). N-acetyl-D-glucosamine is the structural monomer of chitin and is used in the formation of peptidoglycan in bacterial cell walls. Autoradiography indicated that $\mathrm{N}$-acetyl-glucosamine is used by bacteria in all freshwater systems studied (Nedoma et al. 1994), and chitinase gene diversity was correlated with crustacean zooplankton biomass in a mesotrophic lake (Beier et al. 2012). Many marine bacteria also have the ability to utilize $\mathrm{N}$-acetyl-D-glucosamine as a potential carbon and nitrogen source (Riemann \& Azam 2002).

During October, November, March and April, less commonly utilized substrates such as phenolic compounds 2-hydroxybenzoic acid and 4-hydroxybenzoic acid were responsible for the temporal differences in substrate usage by zooplankton-associated bacteria (Fig. 4, Table 3). Both phenolic compounds are components of lignin contained in the seagrass Zostera marina (Klap et al. 2000), which grows in dense beds in the York River near the sampling site (Moore 2009). Seagrass beds in this area typically die back during late September (Moore et al. 2000), but degradation of lignin is slow: only $10 \%$ of lignin was mineralized after a 23-d incubation (Benner et al. 1984). A second pulse of lignin may be added to the system via allochthonous material with the spring freshet, which typically occurs in the York River around March and April (Marshall \& Alden 1990, Kniskern \& Kuehl 2003).

While these carbon substrates may potentially be broken down by the zooplankter's digestive enzymes (Mayzaud 1986), cleavage by digestive enzymes alone would not produce a color change of the redox dye. The colorless tetrazolium violet acts as an alternative electron acceptor in the electron transport chain and is reduced to purple formazan (Seidler 1991), which is then quantified spectrophotometrically. Therefore, unless the substrate is broken down to fuel cellular respiration, a color change will not occur.

\section{Environmental influence on bacterial communities}

Temporal changes in zooplankton-associated BCC (Fig. 2) suggested that ambient environmental conditions were a stronger selective force on zooplanktonassociated bacteria than zooplankton-specific selective forces. Likewise, Kan et al. (2007) noted a similar bacterial composition throughout Chesapeake Bay at any given point in time. However, large seasonal changes in the bacterial communities indicated that environmental conditions with strong seasonality, such as temperature, played a larger role in shaping the microbial community than any region-specific characteristics. The community composition of aquatic free-living and particle-associated bacteria can be shaped by biological, chemical and physical parameters such as temperature (Muylaert et al. 2002, Fuhrman et al. 2006, Kan et al. 2006, Rösel et al. 2012), chlorophyll concentration (Muylaert et al. 2002, Kan et al. 2006), nitrogen and phosphorus concentrations (Muylaert et al. 2002, Fuhrman et al. 2006, Longmuir et al. 2007, Leflaive et al. 2008, Rösel et al. 2012), and grazing pressure (Muylaert et al. 2002). Our results indicate that environmental conditions also act directly on the zooplankton-associated communities, shaping them as they do free-living bacterial communities. Alternatively, the influence may be indirect, with environmental conditions shaping the free-living and particle-associated bacterial communities, which ultimately serve as sources for zooplankton-associated bacteria.

The variation in BCC explained by measured environmental conditions $(37 \%$ for all zooplanktonassociated bacteria, $65.8 \%$ for Acartia-associated) 
was within the range of previous studies of freeliving bacteria in lakes (Lindström 2000, Longmuir et al. 2007, Muylaert et al. 2002). Other unmeasured parameters such as DOC may also impact BCC. However, a large portion of the riverine DOC is likely refractory (Raymond \& Bauer 2001), and by comparison DOC produced by zooplankton excretions tends to be of high quality (Møller 2005, Møller et al. 2007). The relative importance of ambient and zooplanktonproduced DOC for zooplankton-associated bacteria remains to be investigated.

Physical properties of the study system likely also contributed to changes in zooplankton-associated $\mathrm{BCC}$. Water residence time in the York River near our sampling site is approximately $11 \mathrm{~d}$ (Shen \& Haas 2004). The rapid movement of water can continually move free-living bacteria into and out of the system, preventing the establishment of a stable estuarine bacterial community (Crump et al. 1999). Since the external surfaces of zooplankton must be recolonized by a subset of the free-living bacteria after each molting event, the turnover of zooplankton-associated bacterial communities in a dynamic estuary may be much faster than in more stable freshwater or marine systems.

\section{Zooplankton-associated versus free-living bacteria}

The number of DGGE bands detected in this study within the free-living bacterial community is low compared to literature values for Chesapeake Bay (Kan et al. 2006, 2007). The low DGGE band numbers could be due to the dominance of a few phylotypes within the system, as DGGE only detects phylotypes that contribute $>1 \%$ of the total DNA (Muyzer et al. 1993). Additionally, DGGE primers may have created a bias against some bacterial groups such as Gammaproteobacteria (Alonso-Sáez et al. 2007, Gerdts et al. 2013), which comprised a number of the DGGE bands detected by Kan et al. $(2006,2007)$ with a different set of primers. Future studies should utilize a different set of primers or use multiple methods to investigate BCC (Alonso-Sáez et al. 2007, Gerdts et al. 2013). Despite the potential bias, the numbers of DGGE bands recovered from zooplankton were similar to those observed in previous studies (Møller et al. 2007, Tang et al. 2009a, Brandt et al. 2010), and comparisons can still be made among the different samples.

The significant difference between zooplanktonassociated and free-living bacterial communities (Fig. 2) underpins the idea that zooplankton create microhabitats supporting a bacterial community different from that in the surrounding water (Grossart \& Tang 2010). Of the 36 DGGE bands detected, 13 were unique to zooplankton-associated communities, 11 were found only in free-living bacterial communities, and 12 were shared by both communities. These results support the notion of an active exchange between free-living and zooplankton-associated bacterial communities (Møller et al. 2007, Grossart et al. 2010).

The average month-to-month similarity in substrate usage among zooplankton-associated bacteria (63.9\%, Fig. 4) was slightly higher than that among free-living bacteria $(55.1 \%)$. Free-living bacteria in the York River previously showed distinct changes in the carbon substrate usage patterns between winter/ spring and summer/fall bacterial communities (Schultz \& Ducklow 2000). In the Mediterranean Sea, bacteria within a eutrophic harbor showed stable, consistent substrate usage through time (Montserrat Sala et al. 2006). The authors hypothesized that a stable DOC supply allowed a stable bacterial community to establish and use a limited number of substrates. While the present study indicates that zooplankton-associated bacteria can be influenced by ambient environmental conditions, zooplankton themselves constantly produce large amounts of DOC and nutrients (e.g. Gaudy et al. 2000, Møller 2005), creating a stable baseline microenvironment. Thus, the impacts of ambient environmental fluctuations on bacterial communities may be buffered in the zooplankton microenvironment. This unique zooplankton microenvironment could allow certain bacteria to persist in a system even when ambient water conditions are not conducive for their growth (Tang et al. 2011).

The lower number of DGGE bands but similar number of substrates utilized by zooplankton-associated bacteria suggests that zooplankton-associated bacteria may exhibit a larger degree of functional plasticity, while free-living bacteria are more functionally redundant. Bacterial colonization of the macroalga Ulva australis has been described by the competitive lottery model (Burke et al. 2011), where a number of bacterial species with the same functional capacity are present within a source community, and specific niches in the Ulva ecosystem are randomly filled by whichever species from the source community arrived first (Burke et al. 2011). Our findings support the suggestion of Gerdts et al. (2013) that zooplankton may be colonized in the same manner, with functional niches filled by a subset of a more genetically diverse free-living bacterial com- 
munity. The functionality of free-living bacteria is limited by the availability of substrates in the water column. In contrast, bacteria associated with zooplankton would have access to substrates in the water column as well as substrates generated by the zooplankter via ingestion, excretion and sloppy feeding. Thus, the zooplankton-associated bacterial community would have the opportunity to exploit a wider array of substrates.

\section{CONCLUSIONS}

This study demonstrates that seasonal changes in ambient environmental conditions impact the community composition and functionality of zooplanktonassociated bacteria. Zooplankton create microenvironments within the water column that allow certain bacterial groups to flourish, increasing their overall presence and importance within an aquatic system. Taking into account zooplankton-associated bacteria will not only lead to better estimations of total bacterial abundance within a system, but also of the system's overall bacterial diversity and functionality.

Acknowledgements. The authors thank Q. Roberts and S. Baer for assistance in nutrient analysis, S. Pinnow and C. Dziallas for assistance with DGGE analyses, F.C. Dobbs for helpful suggestions on the manuscript and 3 anonymous reviewers for their comments. This research was funded by the National Science Foundation OCE-0814558. S.L.B. received additional support from the National Science Foundation GK-12 (Division of Graduate Education 0840804) and a Leibniz Institute of Freshwater Ecology and Inland Fisheries PhD fellowship. K.W.T. was also supported by a Humboldt Foundation Fellowship for Experienced Researcher, and H.P.G. was supported by the German Science Foundation (GR 1540/20-1). This is contribution number 3321 of the Virginia Institute of Marine Science.

\section{LITERATURE CITED}

Alonso-Sáez L, Balagué V, Sá EL, Sánchez JM and others (2007) Seasonality in bacterial diversity in north-west Mediterranean coastal waters: assessment through clone libraries, fingerprinting and FISH. FEMS Microbiol Ecol 60:98-112

> Beier S, Mohit V, Ettema TJG, Östman Ö, Tranvik LJ, Bertilsson S (2012) Pronounced seasonal dynamics of freshwater chitinase genes and chitin processing. Environ Microbiol 14:2467-2479

- Benner R, Newell SY, Maccubbin AE, Hodson RE (1984) Relative contributions of bacteria and fungi to rates of degradation of lignocellulosic detritus in salt marsh sediments. Appl Environ Microbiol 48:36-40

> Bochner BR (1989) Sleuthing out bacterial identities. Nature 339:157-158
Borcard D, Gillet F, Legendre P (2011) Numerical ecology with R. Springer, New York, NY

Brandt P, Gerdts G, Boersma M, Wiltshire KH, Wichels A (2010) Comparison of different DNA-extraction techniques to investigate the bacterial community of marine copepods. Helgol Mar Res 64:331-342

Burke C, Steinberg P, Rusch D, Kjelleberg S, Thomas T (2011) Bacterial community assembly based on functional genes rather than species. Proc Natl Acad Sci USA 108:14288-14293

> Carman KR (1994) Stimulation of marine free-living and epibiotic bacterial activity by copepod excretions. FEMS Microbiol Ecol 14:255-261

> Choi K, Dobbs FC (1999) Comparison of two kinds of Biolog microplates (GN and ECO) in their ability to distinguish among aquatic microbial communities. J Microbiol Methods 36:203-213

Christian BW, Lind OT (2006) Key issues concerning Biolog use for aerobic and anaerobic freshwater bacterial community-level physiological profiling. Int Rev Hydrobiol 91:257-268

> Crump BC, Hobbie JE (2005) Synchrony and seasonality in bacterioplankton communities of two temperate rivers. Limnol Oceanogr 50:1718-1729

> Crump BC, Armbrust EV, Baross JA (1999) Phylogenetic analysis of particle-attached and free-living bacterial communities in the Columbia River, its estuary and the adjacent coastal ocean. Appl Environ Microbiol 65: 3192-3204

$>$ Dice LR (1945) Measures of the amount of ecologic association between species. Ecology 26:297-302

> Freese HM, Schink B (2011) Composition and stability of the microbial community inside the digestive tract of the aquatic crustacean Daphnia magna. Microb Ecol 62: 882-894

Fuhrman JA, Hewson I, Schwalbach MS, Steele JA, Brown MV, Naeem S (2006) Annually reoccurring bacterial communities are predictable from ocean conditions. Proc Natl Acad Sci USA 103:13104-13109

> Gaudy R, Cervetto G, Pagano M (2000) Comparison of the metabolism of Acartia clausi and A. tonsa: influence of temperature and salinity. J Exp Mar Biol Ecol 247:51-65

> Gerdts G, Brandt P, Kreisel K, Boersma M, Schoo KL, Wichels A (2013) The microbiome of North Sea copepods. Helgol Mar Res 67:757-773

> Grossart HP, Tang KW (2010). www.aquaticmicrobial.net. Commun Integr Biol 3:491-494

> Grossart HP, Dziallas C, Tang KW (2009) Bacterial diversity associated with freshwater zooplankton. Environ Microbiol Rep 1:50-55

Grossart HP, Dziallas C, Leunert F, Tang KW (2010) Bacteria dispersal by hitchhiking on zooplankton. Proc Natl Acad Sci USA 107:11959-11964

Hansen B, Bech G (1996) Bacteria associated with a marine planktonic copepod in culture. I. Bacterial genera in seawater, body surface, intestines and fecal pellets and succession during fecal pellet degradation. J Plankton Res 18:257-273

> Harris JM (1993) The presence, nature, and role of gut microflora in aquatic invertebrates: a synthesis. Microb Ecol 25:195-231

Heidelberg JF, Heidelberg KB, Colwell RR (2002) Bacteria of the $\gamma$-subclass Proteobacteria associated with zooplankton in Chesapeake Bay. Appl Environ Microbiol 68: 5498-5507 
Homonnay ZG, Kéki Z, Márialigeti K, Tóth EM (2012) Bacterial communities in the gut of the freshwater copepod Eudiaptomus gracilis. J Basic Microbiol 52:86-90

Kan J, Byron C, Crump, Wang K, Chen F (2006) Bacterioplankton community in Chesapeake Bay: predictable or random assemblages. Limnol Oceanogr 51:2157-2169

Kan J, Suzuki MT, Wang K, Evans SE, Chen F (2007) High temporal but low spatial heterogeneity of bacterioplankton in the Chesapeake Bay. Appl Environ Microbiol 73: 6776-6789

Klap VA, Hemminga MA, Boon JJ (2000) Retention of lignin in seagrasses: angiosperms that returned to the sea. Mar Ecol Prog Ser 194:1-11

Kniskern TA, Kuehl SA (2003) Spatial and temporal variability of seabed disturbance in the York River subestuary. Estuar Coast Shelf Sci 58:37-55

Konopka A, Oliver L, Turco RF Jr (1998) The use of carbon substrate utilization patterns in environmental and ecological microbiology. Microb Ecol 35:103-115

Koroleff F (1983) Determination of nutrients. In: Grasshoff K, Ehrhardt M, Kremling K (eds) Methods of seawater analysis, 2nd edn. John Wiley \& Sons, New York, NY, p 125-187

Leflaive J, Danger M, Lacroix G, Lyautey E, Oumarou C, Ten-Hage L (2008) Nutrient effects on the genetic and functional diversity of aquatic bacterial communities. FEMS Microbiol Ecol 66:379-390

> Lindström ES (2000) Bacterioplankton community composition in five lakes differing in trophic status and humic content. Microb Ecol 40:104-113

> Longmuir A, Shurin JB, Clasen JL (2007) Independent gradients of producer, consumer, and microbial diversity in lake plankton. Ecology 88:1663-1674

Lyons MM, Dobbs FC (2012) Differential utilization of carbon substrates by aggregate-associated and waterassociated heterotrophic bacterial communities. Hydrobiologia 686:181-193

> Lyons MM, Ward JE, Gaff H, Hicks RE, Drake JM, Dobbs FC (2010) Theory of island biogeography on a microscopic scale: organic aggregates as islands for aquatic pathogens. Aquat Microb Ecol 60:1-13

Marshall HG, Alden RW (1990) A comparison of phytoplankton assemblages and environmental relationships in three estuarine rivers of the lower Chesapeake Bay. Estuaries 13:287-300

Mayzaud P (1986) Digestive enzymes and their relation to nutrition. In: Corner EDS, O'Hara SCM (eds) The biological chemistry of marine copepods. Clarendon Press, Oxford, p 165-225

Møller EF (2005) Sloppy feeding in marine copepods: preysize-dependent production of dissolved organic carbon. J Plankton Res 27:27-35

> Møller EF, Riemann L, Søndergaard M (2007) Bacteria associated with copepods: abundance, activity and community composition. Aquat Microb Ecol 47:99-106

Montserrat Sala M, Arin L, Balagué V, Felipe J, Guadayol Ò, Vaqué D (2005) Functional diversity of bacterioplankton assemblages in western Antarctic seawaters during late spring. Mar Ecol Prog Ser 292:13-21

> Montserrat Sala M, Estrada M, Gasol J (2006) Seasonal changes in the functional diversity of bacterioplankton in contrasting coastal environments of the NW Mediterranean. Aquat Microb Ecol 44:1-9

Moore KA (2009) Submerged aquatic vegetation of the York River. J Coast Res 57:50-58
Moore KA, Wilcox DJ, Orth RJ (2000) Analysis of the abundance of submersed aquatic vegetation communities in the Chesapeake Bay. Estuaries 23:115-127

> Muylaert K, Van der Gucht K, Vloemans N, Meester LD, Gillis M, Vyverman W (2002) Relationship between bacterial community composition and bottom-up versus topdown variables in four eutrophic shallow lakes. Appl Environ Microbiol 68:4740-4750

Muyzer G, Ramsing NB (1995) Molecular methods to study the organization of microbial communities. Water Sci Technol 32:1-9

> Muyzer G, De Waal EC, Uitterlinden AG (1993) Profiling of complex microbial populations by denaturing gradient gel electrophoresis analysis of polymerase chain reaction-amplified genes coding for 16S rRNA. Appl Environ Microbiol 59:695-700

> Nedoma J, Vrba J, Hejzlar J, Šimek K, Straškrabová V (1994) N-acetylglucosamine dynamics in freshwater environments: concentration of amino sugars, extracellular enzyme activities and microbial uptake. Limnol Oceanogr 39:1088-1100

> Newton RJ, Jones SE, Eiler A, McMahon KD, Bertilsson S (2011) A guide to the natural history of freshwater lake bacteria. Microbiol Mol Biol Rev 75:14-49

- Niswati A, Murase J, Kimura M (2005) Comparison of bacterial communities associated with microcrustaceans from the floodwater of a paddy field microcosm: estimation based on DGGE pattern and sequence analyses. Soil Sci Plant Nutr 51:281-290

Oksanen J, Blanchet FG, Kindt R, Legendre P and others (2012). vegan: community ecology package. $\mathrm{R}$ package version 2.0-5. CRAN.R-project.org/package=vegan

Parsons TR, Maita Y, Lalli CM (1984) A manual of chemical and biological methods for seawater analysis. Pergamon Press, New York, NY

- Parveen B, Reveilliez J, Mary I, Ravet V and others (2011) Diversity and dynamics of free-living and particleassociated Betaproteobacteria and Actinobacteria in relation to phytoplankton and zooplankton communities. FEMS Microbiol Ecol 77:461-476

> Porter KG, Feig YS (1980) The use of DAPI for identifying and counting aquatic microflora. Limnol Oceanogr 25: 943-948

R Core Team (2012) R: A language and environment for statistical computing. R Foundation for Statistical Computing, Vienna

Raymond PA, Bauer JE (2001) DOC cycling in a temperate estuary: a mass balance approach using natural ${ }^{14} \mathrm{C}$ and ${ }^{13} \mathrm{C}$ isotopes. Limnol Oceanogr 46:655-667

> Reiss H, Kröncke I (2005) Seasonal variability of infaunal community structures in three areas of the North Sea under different environmental conditions. Estuar Coast Shelf Sci 65:253-274

Riemann L, Azam F (2002) Widespread N-acetyl-Dglucosamine uptake among pelagic marine bacteria and its ecological implications. Appl Environ Microbiol 68: 5554-5562

Ritchie KB, Smith GW (1995) Preferential carbon utilization by surface bacterial communities from water mass, normal and white-band diseased Acropora cervicornis. Mol Mar Biol Biotechnol 4:345-352

Rösel S, Allgaier M, Grossart HP (2012) Long-term characterization of free-living and particle-associated bacterial communities in Lake Tiefwaren reveals distinct seasonal patterns. Microb Ecol 64:571-583 
Schultz GE, Ducklow HW (2000) Changes in bacterioplankton metabolic capabilities along a salinity gradient in the York River estuary, Virginia, USA. Aquat Microb Ecol 22: 163-174

Shen J, Haas L (2004) Calculating age and residence time in the tidal York River using three-dimensional model experiments. Estuar Coast Shelf Sci 61:449-461

Seidler E (1991) The tetrazolium-formazan system: design and histochemistry. Prog Histochem Cytochem 24:1-86

Tang KW (2005) Copepods as microbial hotspots in the ocean: effects of host feeding activities on attached bacteria. Aquat Microb Ecol 38:31-40

Tang KW, Grossart HP (2007) Iron effects on colonization, motility and enzymatic activities of marine bacteria. Can J Microbiol 53:968-974

Tang KW, Visscher PT, Dam HG (2001) DMSP-consuming bacteria associated with the calanoid copepod Acartia tonsa (Dana). J Exp Mar Biol Ecol 256:185-198

Tang KW, Hutalle KML, Grossart HP (2006) Microbial abundance, composition and enzymatic activity during decomposition of copepod carcasses. Aquat Microb Ecol

Editorial responsibility: Eva Lindström,

Uppsala, Sweden
45:219-227

Tang KW, Dziallas C, Hutalle-Schmelzer K, Grossart HP (2009a) Effects of food on bacterial community composition associated with the copepod Acartia tonsa Dana. Biol Lett 5:549-553

Tang KW, Bickel SL, Dziallas C, Grossart HP (2009b) Microbial activities accompanying decomposition of cladoceran and copepod carcasses under different environmental conditions. Aquat Microb Ecol 57:89-100

Tang KW, Turk V, Grossart HP (2010) Linkage between crustacean zooplankton and aquatic bacteria. Aquat Microb Ecol 61:261-277

Tang KW, Dziallas C, Grossart HP (2011) Zooplankton and aggregates as refuge for aquatic bacteria: protection from UV, heat and ozone stresses used for water treatment. Environ Microbiol 13:378-390

Zak JC, Willig MR, Moorhead DL, Wildman HG (1994) Functional diversity of microbial communities: a quantitative approach. Soil Biol Biochem 26:1101-1108

Zhou J, Bruns M, Tiedje J (1996) DNA recovery from soils of diverse composition. Appl Environ Microbiol 62:316-322

Submitted: June 26, 2013; Accepted: October 23, 2013

Proofs received from author(s): January 31, 2014 